\title{
Investigating the relationship between marketing mix of Parsian banking services and customer loyalty according to the mediating role of customer satisfaction
}

\author{
Abulfazl SOHRABI ${ }^{1}$, Sadaf KHANBOLOOKI ${ }^{2}$, Toktam GHAZAVI ${ }^{3}$ \\ ${ }^{1}$ Faculty member of Qom Paradise University, Qom, Iran \\ ${ }^{2}$ Young Researcher and Elite Club, Qom Branch, Islamic Azad University, Qom, Iran \\ ${ }^{3}$ Department of business management, Science and Research Branch, Islamic Azad University, \\ Tehran, Iran
}

\begin{abstract}
Today, many economic sectors such as banking industry have understood the necessity of paying due attention to customers. Retaining and attracting customers is an important factor for the success and achievement of competitive advantage. The present study aimed to investigate the relationship between marketing mix of Parsian bank banking services and customer loyalty considering the mediating role of customer satisfaction. The research method in this study is quantitative-inductive. Findings are obtained with regard to the views of 388 customers of Parsian bank branches in Tehran. Data analysis is done using confirmatory factor analysis and process analysis of covariance structures (structural equation modeling). The results of this study indicate that the measurement tool is reliable and valid and the research model has a good fit. The marketing mix has a significant positive effect on customer loyalty through customer satisfaction both directly and indirectly.
\end{abstract}

Keywords: Marketing, marketing mix, service, customer satisfaction, customer loyalty, bank

\section{Introduction}

In today's competitive and challenging environment, organizations emphasize the establishment of sustainable and profitable relationships with customers more than anything. On its evolution path, marketing is in a stage that marketers do not just think about new customers. Customer satisfaction is not sufficient now and companies should ensure that their satisfied customers are loyal. In this environment, in addition to trying to acquire new customers, new marketing leads companies to retain current customers and create a permanent relationship with them (Tabatabaenasab, 2007). With respect to the necessity of customer orientation in today's business management scenario, it is understood that customer is the main capital of business process and organization's success depends on the management of efficient relationship with customers since attracting new customers costs so much (Chiou, Drog, 2006). On the other hand, customer 
loyalty brings about lots of benefits for companies such as increasing income and causing loyal customers transfer their satisfaction to other friends (Duffy, 2003).

Customers are the key and pivotal factor in promoting and strengthening organizations and orientation of all objectives, strategies, and resources are focused on attracting and keeping customers. Customer retention for companies concerned with maintaining and developing their competitive position in the market is considered a strategic challenge (Sutton \& Klein, 2003). Thorough knowledge of customers regarding the market and access to information has caused customers to be less loyal toward the organization. Therefore, organizations are looking for ways to create loyal customers (Oly Ndubisi \& Kok Wah, 2005).

Service sector is one of the key economic sectors of any country and banks, as service organizations, play an important role in the economic growth and development of countries. Banks can highly affect economic growth of countries through customer satisfaction and encouraging them to savings and capital accumulation and using them in manufacturing and consumption industries (Ashrafi, 2007). In past years, the banking industry of Iran has neglected customer orientation and its pillars due to different economic and social problems, being governmental, and most importantly the increase of demand over supply. However, with the arrival of private sector banks, the industry has gradually step toward being more competitive. Therefore, banks must guide and implement systems for establishing customer satisfaction and ultimately customer loyalty by clearly identifying factors affecting customer satisfaction (Abdolvand, Abdolu, 2007). In the meanwhile, organizations capable of rapid responding have the feature to effectively react to changes, change threats to opportunities, and optimally use opportunities. "Rapid response capability is interpreted as using market knowledge to take advantage of profitable opportunities in a fickle market" (Sutton \& Klein, 2003).Institutions and banks should strive to gain a proper share of market by studying market and using marketing mix variables. They should also act more practically using desirable distribution methods and supplying good services, using informing ads, identifying opportunities and using them to attract more resources. In addition, they should attempt to increase market share and customers through creativity and innovation as well as matching resources with the needs of customers (Nazari, 2011).

Marketing mix elements are control tools in the hands of the organization that lead to customer satisfaction (Shankar \& Chin, 2011). A clear understanding of marketing mix elements by service providers will have an influence on potential and current customers, convert them to loyal customers, and help them continue their business life (Wahab et al., 2016).

This research seeks to answer the question of whether there is a significant relationship between banking services' marketing mix and customer satisfaction and loyalty in Parsian Bank.

\section{Literature review}




\subsection{Marketing Mix}

The traditional concept of marketing mix was first defined by Borden in 1948. However, the most durable and popular definition of marketing mix elements is the definition provided by McCarthy that combines all twelve elements together and considered four elements as marketing elements (Rafiq and Ahmed, 1995). McCarthy (1964) states that marketing mix is a combination of all the factors that marketing managers put on agenda to satisfy and meet the needs of the target market, which includes four dimensions of product, price, place and promotion(McCarthy, 1964).

Combining marketing elements is one of the fundamental concepts in marketing. Marketing mix refers to a set of factors and elements affecting marketing and is one the tools available for the organization through which any organization can provide its goods or services in the best way. Marketing mix leads to the accomplishment of organizational strategies and achievement of organization's goals (Borden, 1964).

Like goods, services are alsoa combination of marketing elements; interaction of these elements with each other and using them in the marketing process leads to the success of service organizations (Kotler et al., 2008). Service marketing mix is different from good marketing mix due to the different nature of services (intangibility, inseparability, variability and mortality). Booms and Bitner (1981) added three other factors including people, physical evidence, and process to good mix elements (Booms, Bitner, 1981). In this research, service marketing mix of Booms and Bitner (1981) will be used, which has seven dimensions:

- Product: is the first factor and core of marketing mix, because as long as there is no product or service, other marketing elements lose their meaning. In this regard, it should be attempted to make the services tangible through visible features (Al-Dmour et al., 2013).

- Price: in consumer markets, price is an external expression of product quality and thus, highpriced brands are often thought to be of higher quality. However, with regard to the goods, product quality can be partially substantiated and observed before buying (Kim, Hyum, 2011). The price dimension includes determining the level of prices, the pricing method, strategies and methods and terms of payment in services (Kotler et al., 2008).

- Place and distribution: place and location of service provision is one of the most important topics in services marketing management that in addition to making the service tangible, is of importance to speed up and simplify and gain access to important services. Due to theintegral nature of service providers, place and distribution are important factors in service marketing strategy. When the distribution system is improved, customers make less effort to find the desired brand, which affects their level of perceived quality (Kotler et al., 2008).

- Promotion: promotion includes all communications that service supplier creates in the market (Martínez et al., 2009). The use of all elements of communication such as advertising, sales 
promotion, public information and personal selling are important in the awareness and encouragement and persuasion of people to use services and require special strategies (Kotler et al., 2008).

- People: due to simultaneous supply and demand of services and the relationship between service and servant, the role of each employee in the service is important and necessary precision should be devoted to the selection, education, motivation and other human resources' factors related to staff (Kotler et al., 2008).Considering the importance of people in an organization's strategy design, emphasis will be on improving staff.

- Physical evidence: each service organization requires a variety of physical and material tools and facilities to provide services and actualize potential services. As much as these services are more up to date and more qualitative, they will lead to customer satisfaction (Kotler et al., 2008).

- Processes:the management and marketing process of services has a very important role in the how and quality of service. The process of service provision must be based on possibilities, limitations, and supply and demand conditions. The simpler the service process, the faster and easier customers feel relaxed and satisfied (Kotler et al., 2008). Process refers to procedures, mechanisms and activities needed to provide services (Palmer, 2005).

\subsection{Customer satisfaction}

Customer satisfaction is defined as a positive affective state obtained from evaluating a company in terms of all communications with other organization or party (Anderson, Narus, 1990). Customer satisfaction is a cumulative experience of buying and consuming and is influenced by two factors of expectations and experienced service performance. Customer satisfaction can thus be defined as the feeling of pleasure or disappointment as a result of comparing the results with expectations (Kotler, Armstrong, 1999).

\subsection{Customer loyalty}

The most acceptable definition for loyalty goes back to the definition of Yakoubi and kinner (1973) in which loyalty is defined as prejudice ofa brand and behavioral response over time, where a person prefers a particular brand over other brands and will decide about it a mental commitment (Mcmullan, Gilmore, 2008).

Customer loyalty is a deep-seated internal commitment that leads to repurchase or reuse of a specific product or service (Yau, 2000). Loyalty refers to the highest acceptance level of a brand by customers that is usually visible in customers' buying behavior. Loyal customers buy more frequently and even recommend the brand to others (Nguyen et al., 2011).

Conceptually, customer loyalty can include behavioral, attitude and hybrid approach. Behavioral approach focuses on customers' behavior in repurchasing. Attitude approach refers to the favorable orientation toward product provider. Finally, hybrid approach means combining 
definitions of behavioral and attitude loyalty (Zins, 2001). In this study, the hybrid approach has been taken into account.

\subsection{The relationship between research variables}

In this regard, the strong impact of customer satisfaction on brand loyalty has been researched and proven (Krystallis, Chrysochou, 2013). Before being loyal, customers need to be satisfied (Wahab et al., 2016).Based on the relationship with customers, it has been proven that customer satisfaction gradually creates a sense of loyalty and trust in the organization. In addition to referring to the organization for re-purchasing favorite products and services, a loyal customer, as an additional factor in promoting the products and services of the organization through recommending relatives, friends or other people, plays an important role in increasing profitability and improving the company's image in the minds of potential customers (Cina, 2013).

\section{Service customer loyalty}

Yakoubi and Chestnut's (1978) analysis shows that continuing to buy is not a marker of customer loyalty and may be due to the purchase method or priority of customer convenience or other factors. Therefore, batch purchases could diminish the loyalty of customer. Service customer loyalty is a different concept than other loyalty constructs since it largely depends on the development of interpersonal relationships. In services, intangible characteristics such as reliability play a major role in creating or maintaining customer loyalty. In Jarvis and Mayo's (1986) terms, service loyalty leads to repeat purchase behaviors among customer service and create a positive attitude towards the company. Meidan (1996) believed that the degree of loyalty in the banking industry can be defined by tracking customer accounts during a defined period of time and considering the degree of continuing commitment. However, behavioral measures such as consecutive buying or meetings have been criticized due to the lack of a conceptual basis. Bloomer et al. (1998) define loyalty to the bank as behavioral responses associated with bias (non-random) or re-meeting that are expressed through some decision-making units to a bank over time, which is a function of psychological processes (decision-making and evaluative) and results in commitments to the brand (Zamani Moghadam and Lahiji, 2012).Considering the material presented, the effectiveness of banking service marketing on customer loyalty is actually included in the concept of service customer loyalty. 
Bulletin de la Société Royale des Sciences de Liège, Vol. 86, special edition, 2017, p.421 - 433

\section{Research background}

Table 1: A summary of domestic and foreign studies conducted

\begin{tabular}{|c|c|c|c|}
\hline Authors & Year & Title & Results \\
\hline $\begin{array}{c}\text { Zare } \\
\text { Ahmadabadi and } \\
\text { Hatami Nasab }\end{array}$ & 2009 & $\begin{array}{l}\text { Investigating the quality of e-service } \\
\text { provision in improving the relationship } \\
\text { between customer and organization } \\
\text { (case study of customers of Tejarat } \\
\text { bank branched in Shiraz and Yazd) }\end{array}$ & $\begin{array}{l}\text { Bank branches' customer satisfaction is different in } \\
\text { terms of different dimensions of WebQual based on } \\
\text { biographical characteristics and electronic use. }\end{array}$ \\
\hline $\begin{array}{l}\text { Hamidizadeh } \\
\text { and Ghamkhari }\end{array}$ & 2009 & $\begin{array}{l}\text { Identifying factors affecting customer } \\
\text { loyalty based on rapid response } \\
\text { organizations model }\end{array}$ & $\begin{array}{l}\text { Each six dimensions of rapid response } \\
\text { organizations model affects customer loyalty. }\end{array}$ \\
\hline $\begin{array}{c}\text { Zamani } \\
\text { Moghadam and } \\
\text { Lahiji }\end{array}$ & 2012 & $\begin{array}{l}\text { Investigating factors affecting Parsian } \\
\text { and Eghtesad-E Novin private banks' } \\
\text { customer loyalty based on rapid } \\
\text { response organization model }\end{array}$ & $\begin{array}{l}\text { Although private banks are in good conditions in } \\
\text { terms of quality of service, reliability and speed of } \\
\text { delivery and have been successful in creating an } \\
\text { appropriate image in the minds of customers to a } \\
\text { large extent, they are at a lower level in terms of } \\
\text { flexibility and innovation. }\end{array}$ \\
\hline Ball et al. & 2004 & $\begin{array}{l}\text { The role of communication and trust in } \\
\text { explainingcustomer loyalty an } \\
\text { extension to the ECSI Model }\end{array}$ & $\begin{array}{l}\text { Customer loyalty is a significant degree of } \\
\text { customer satisfaction, trust and communication. }\end{array}$ \\
\hline $\begin{array}{l}\text { Howcroft \& } \\
\text { Hamilton }\end{array}$ & 2007 & $\begin{array}{l}\text { Customer involvement and interaction } \\
\text { in retail banking : an examination of } \\
\text { risk and confidence in the purchase of } \\
\text { financial products }\end{array}$ & $\begin{array}{l}\text { Market is composed of a number of distinct } \\
\text { customers; although market may change, it should } \\
\text { be recognized that the majority of bank customers } \\
\text { are affected. }\end{array}$ \\
\hline $\begin{array}{l}\text { Krystallis, } \\
\text { Chrysochou }\end{array}$ & 2013 & $\begin{array}{c}\text { The effects of service brand } \\
\text { dimensions on brand loyalty. Journal of } \\
\text { Retailing and Consumer Services }\end{array}$ & $\begin{array}{c}\text { Brand loyalty has a significant relationship with } \\
\text { customer satisfaction and behavioral attitude and } \\
\text { loyalty. Advertisement has also no effect on } \\
\text { customer satisfaction. }\end{array}$ \\
\hline $\begin{array}{l}\text { 'AL-Dmour et } \\
\text { al. }\end{array}$ & 2013 & $\begin{array}{l}\text { The effect of services marketing mix } \\
\text { elements on customer-based brand } \\
\text { equity: An empirical study on mobile } \\
\text { telecom service recipients in Jordan }\end{array}$ & $\begin{array}{l}\text { Customer-based brand is a valuable asset for each } \\
\text { service sector. }\end{array}$ \\
\hline
\end{tabular}

\section{Methodology}

Based on the literature review, the following model is selected as the conceptual model of this study: 


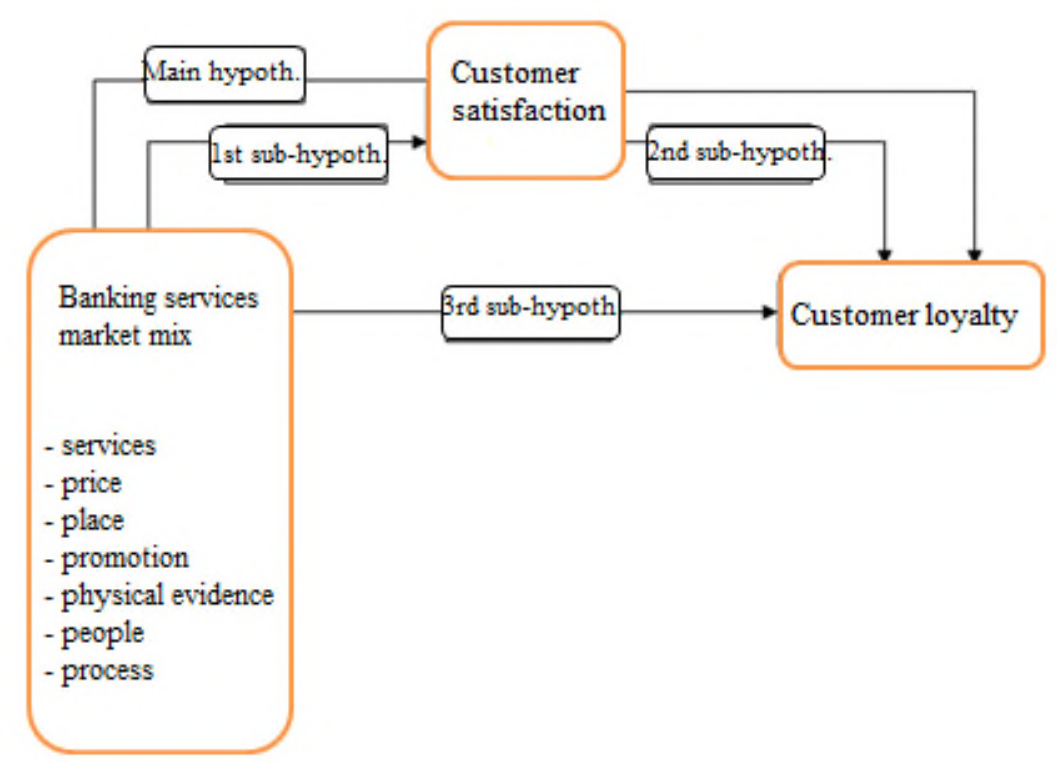

(Source: Abd Wahab et al., 2016)

The present study is quantitative-inductive. It is also applied in terms of its objective and is descriptive-survey in terms of data collection method.

The study population of this study consists of customers of all the branches of Parsian Bank in Tehran. Given the whole number of population and using Cochran formula, the sample size is estimated based on an unlimited population. Finally, 388 questionnaires were responded and returned. Simple random sampling was used to select the sample.

Validity of the questionnaire was investigated through confirmatory factor analysis using smart PLS software and the results of confirmatory factor analysis confirmed the validity.

Reliability of the questionnaire was also investigated through composite reliability and Cronbach's alpha and the results are higher than $70 \%$, indicating high reliability of the questionnaire. 
Bulletin de la Société Royale des Sciences de Liège, Vol. 86, special edition, 2017, p.421 - 433

\section{Data analysis and findings}

\subsection{Descriptive statistics}

Table 2: Descriptive statistics of research variables

\begin{tabular}{|c|c|c|c|}
\hline Variables & No. & Mean & SD. \\
\hline Service characteristics & 388 & 3.26 & 3.092 \\
\hline Price & 388 & 3.17 & 3.381 \\
\hline Place & 388 & 2.47 & 4.628 \\
\hline Promotion & 388 & 3.86 & 2.329 \\
\hline People & 388 & 3.22 & 3.020 \\
\hline Physical evidence & 388 & 3.28 & 4.150 \\
\hline Organizational processes & 388 & 3.31 & 3.940 \\
\hline Customer satisfaction & 388 & 3.65 & 4.910 \\
\hline Customer loyalty & 388 & 3.37 & 2.710 \\
\hline
\end{tabular}

Descriptive statistics of research variables shows that all variables are of mean desirability and place has the lowest mean value. This means that from the customer's perspective, scope and design of Parsian bank branches in Tehran is less than average.

\subsection{Kolmogorov-Smirnov test results}

As can be seen in table 3, the significance level of some variables is higher than the error level of .05 ; therefore, the null hypothesis is not rejected and their normality is accepted. In other variables, the significance level is lower than .05 , indicating the rejection of their normality assumption.

Table 3: Kolmogorov-Smirnov test results

\begin{tabular}{|c|c|c|c|}
\hline Variables & $\mathrm{Z}$ & Sig. level & Normality results \\
\hline Service characteristics & 1.70 & .006 & Not normal \\
\hline Price & 1.84 & .002 & Not normal \\
\hline Place & 1.57 & .014 & Not normal \\
\hline Promotion & 1.06 & .21 & Normal \\
\hline People & 2.35 & .000 & Not normal \\
\hline Physical evidence & 1.37 & .045 & Not normal \\
\hline Organizational processes & 1.22 & .10 & Normal \\
\hline Customer satisfaction & 1.01 & .25 & Not normal \\
\hline Customer loyalty & 1.84 & .002 & \\
\hline
\end{tabular}


Given the uncertainty of response variables' distribution, the complexity of the model (the large number of constructs and indicators), having a multilevel model, and performing a second-order factor analysis and higher, structural equation modeling with partial least square method using smart PLS software is applied to validate the model and respond hypotheses.

\subsection{Validating structural model}

After validating measurement models, it is time to investigate the structural model of the study. The criteria of validating the structural model are presented in table 4.

Table 4: Results of structural equations to investigate research hypotheses

\begin{tabular}{|c|c|c|c|c|c|c|c|}
\hline Effects & $\begin{array}{l}\text { Independent } \\
\text { variables }\end{array}$ & $\begin{array}{l}\text { Dependent } \\
\text { variables }\end{array}$ & Beta & $\mathrm{T}$ & $\overline{\mathrm{R}^{2}}$ & Result & $\begin{array}{l}\text { Direction of the } \\
\text { relationship }\end{array}$ \\
\hline \multirow{3}{*}{$\begin{array}{c}\text { Sub- } \\
\text { hypotheses }\end{array}$} & Marketing mix & Satisfaction & .72 & 27.00 & .52 & Confirmed & + \\
\hline & Satisfaction & loyalty & .43 & 7.66 & \multirow{2}{*}{.39} & Confirmed & + \\
\hline & Marketing mix & loyalty & .24 & 3.77 & & Confirmed & + \\
\hline $\begin{array}{c}\text { Main } \\
\text { hypothesis }\end{array}$ & \multicolumn{2}{|c|}{$\begin{array}{c}\text { Marketing mix ----- satisfaction -- } \\
\text {---- loyalty }\end{array}$} & .30 & 5.43 & .09 & Confirmed & + \\
\hline
\end{tabular}

$|t|>1.96$ Significant at $P<0.05,|t|>2.58$ Significant at $P<0.01$

As the results of structural equation show, all hypotheses have been confirmed. Therefore, marketing mix has a positive significant effect on customer loyalty through customer satisfaction both directly and indirectly.

\section{Discussion and conclusion}

\subsection{Results of investigating each hypothesis}

In general, according to the results of this research, it can be concluded that considering the state of Parsian bank service marketing mix is important. One of the necessities of paying attention to this issue is the influence that marketing mix leaves on customer satisfaction and loyalty. On the other hand, ignoring this issue despite the prevailing market competitors, including other private and public banks, stock, and currency and gold coin markets, can have negative effects on the performance of banks and attract customers and depositors of the Bank to invest in other competitor. The following suggestions are presented separately:

The main hypothesis: Given that it was found that banking services' marketing mic affects loyalty of Parsian Bank customer through the mediating role of customer satisfaction, the role of banking services' marketing should be the priority of the plans and strategies of all Parsian bank branches must be under focused in marketing and advertising activities. Accordingly, as one of the banking services marketing factors is staff, it is necessary to pay due attention to customer orientation in the first step since staff behavior affects customers. Therefore, it is suggested to train staff on how to interact with customers, to identify their needs, including communication 
and behavior skills, have the ability to listen and hear well. The exact definition of standards for hiring, training, motivating, and rewarding staff is essential given the vital role and constant interaction with customers. Parsian Bank can also use polls or interviews with customers to better understand customer needs and thus, take administrative measures to meet their needs in order to cause customer loyalty.

First sub-hypothesis: this hypothesis concludes that banking services marketing mix in Parsian Bank affects customer satisfaction. Therefore, on this basis, it is suggested to establish an independent unit to do market research and survey customers' need to deliver new services given the current situation and changing needs of customers and the need to develop and expand services and facilities. Although Research \& Development Unit is responsible for all these duties in Parsian Bank, it is necessary to establish a strong and independent marketing unit to identify the needs of customers, market segmentation, customer segmentation based on customers whose presence are essential to the life of the bank and implementing future programs.

Second sub-hypothesis: this hypothesis concludes that customer satisfaction affects customer loyalty in Parsian bank. Therefore, it is necessary to pay due attention to customers' needs through forming customer club and giving specific cards to customers in order to provide more effective services. Accordingly, it is suggested to give membership to those who have a defined amount of deposit, and based on criteria such as lack of a dud check, having an account for more than one year, and so on, and in exchange, bank can give services such as giving facilities with easier criteria, discounts on offering banking services' wage, providing delivery services without having to wait an etc. It is better for Parsian bank to focus on these factors and have plans to create more specific and competitive conditions than competitors in the provision of specific services to key customers. In addition, Parsian Bank location and access levels can lead to customer satisfaction and loyalty. Given that there is still great potential for proliferation of bank branches in Tehran, it is recommended to consider this issue.

Third sub-hypothesis: this hypothesis concludes that banking services' marketing mix in Parsian Bank affects customer loyalty. Accordingly, it is recommended to cause loyalty through focusing on customer interaction and attracting customers' participation in programs. Therefore, based on the views of modern marketing, customers can comment on all sectors and all issues related to the organizations. This is because engaging customers and valuing them affects the sense of belonging to the bank and rapid diagnosis of needs and rapid response of Parsian Bank in order to meet their needs.

\section{Resources}

[1] Ashrafi, S. M. (2007). Investigating service quality in public and private bank system using a five-dimensional SERVQUAL model in National Bank of Iran and Parsian Bank. MA thesis, Islamic Azad University of science and research branch, faculty of management and economics. 
[2] Zare Ahmadabadi, H. and Hatami Nasab, H. (2009). Investigating the quality of e-service provision in improving the relationship between customer and organization (case study of customers of Tejarat bank branched in Shiraz and Yazd). First international conference on banking services marketing.

[3] Hamidizadeh, M. and Ghamkhari, M. (2009). Identifying factors affecting customer loyalty based on rapid response organizations model. Quarterly journal of business studies, 52, 187-210.

[4] Zamani Moghadam, A. and Lahiji, K. (2012). Investigating factors affecting Parsian and Eghtesad-E Novin private banks' customer loyalty based on rapid response organization model. Journal of marketing management, 16.

[5] Tabatabaenasab, M. (2008). Designing and explaining customer loyalty model in the banking industry (study scope: Iranina banks). First international conference on banking services' marketing. Tehran, 3-13.

[6] Abdolvand, M.A. and Abdoli, K. (2007). Investigating factors affecting customer loyalty in Tejarat bank. Journal of marketing management, 3(5), 1-20.

[7] Nazari, K. (2011). The effect of marketing mix elements on attracting customers (case study of Saderat Bank in Kermanshah province). Bank and economy, 113, 50-53.

[8] Al-Dmour, H., Zu'bi, M. F., \& Kakeesh, D. (2013). The effect of services marketing mix elements on customer-based brand equity: An empirical study on mobile telecom service recipients in Jordan. International Journal of Business and Management, 8(11), 13-26.

[9] Anderson, J. C., \& Narus, J. A. (1990). A model of distributor firm and manufacturer firm working partnerships. the Journal of Marketing, 42-58.

[10] Ball, D., Coelho, P. S. \& Machas, A. (2004). "The role of communication and trust in explainingcustomer loyalty an extension to the ECSI Model", European Journal of Marketing, pp. 1272-1293.

[11] Booms, B. H., \& Bitner, M. J. (1981). Marketing strategies and organization structures for service firms. Marketing of services, 25(3), 47-52.

[12] Borden, N. H. (1964). The concept of the marketing mix. Journal of advertising research, 4(2), 2-7.

[13] Chiou, J. S., \& Droge, C. (2006). Service quality, trust, specific asset investment, and expertise: Direct and indirect effects in a satisfaction-loyalty framework. Journal of the Academy of Marketing Science, 34(4), 613-627.

[14] Cina, C. (2013). Creating an effective customer satisfaction program. Journal of Consumer Marketing.

[15] Devaraj, S., Fan, M., \& Kohli, R. (2002). Antecedents of B2C channel satisfaction and preference: validating e-commerce metrics. Information systems research, 13(3), 316333.

[16] Duffy, D. L. (2003). Internal and external factors which affect customer loyalty. Journal of consumer marketing, 20(5), 480-485. 
Bulletin de la Société Royale des Sciences de Liège, Vol. 86, special edition, 2017, p.421 - 433

[17] Howcroft, Barry \& Hamilton, Robert (2007). Customer involvement and interaction in retail banking : an examination of risk and confidence in the purchase of financial products. journal of service marketing, vol.21 no.7, pp 481-491.

[18] Kim, J. H., \& Hyun, Y. J. (2011). A model to investigate the influence of marketing-mix efforts and corporate image on brand equity in the IT software sector. Industrial Marketing Management, 40(3), 424-438.

[19] Kotler, P. \& Armstrong, G. (1999). Principles of Marketing. 8th Edition, Prentice-Hall, Upper Saddle River, New Jersey.

[20] Kotler, P., Shalowitz, J., \& Stevens, R. J. (2008). Strategic marketing for health care organizations: building a customer-driven health system. 1st ed. San Francisco: JosseyBass.

[21] Krystallis, A., Chrysochou, P. (2013). The effects of service brand dimensions on brand loyalty. Journal of Retailing and Consumer Services, http://dx.doi.org/10.1016/j.jretconser.2013.07.009i.

[22] Kuikka, A., \& Laukkanen, T. (2012). Brand loyalty and the role of hedonic value. Journal of Product \& Brand Management, 21(7), 529-537.

[23] Kumar, V. I. S. W. A. N. A. T. H. A. N., \& Shah, D. (2004). Building and sustaining profitable customer loyalty for the 21st century. Journal of retailing, 80(4), 317-329.

[24] Martínez, E., Montaner, T., \& Pina, J. M. (2009). Brand extension feedback: The role of advertising. Journal of Business Research, 62(3), 305-313.

[25] McCarthy, E. J. (1964). Basic Marketing: A Managerial Approach, 2nd edn, Homewood, IL: Richard D .Irwin

[26] McMullan, R., \& Gilmore, A. (2008). Customer loyalty: an empirical study. European Journal of Marketing, 42(9/10), 1084-1094.

[27] Nguyen, T. D., Barrett, N. J., \& Miller, K. E. (2011). Brand loyalty in emerging markets. Marketing Intelligence \& Planning, 29(3), 222-232.

[28] Oly Ndubisi, N., \& Kok Wah, C. (2005). Factorial and discriminant analyses of the underpinnings of relationship marketing and customer satisfaction. International journal of bank marketing, 23(7), 542-557.

[29] Palmer, A. (2005). Principles of services marketing. 4th ed, England, McGraw-Hill Book Company Limited.

[30] Rafiq, M., \& Ahmed, P. K. (1995). Using the 7Ps as a generic marketing mix: an exploratory survey of UK and European marketing academics. Marketing Intelligence \& Planning, 13(9), 4-15.

[31] Shankar, C., \& Chin, K. K., 2011. A study of the relationship between marketing mix and customer retention for herbal coffee in Malaysia. 2nd International Conference on Business and Economic Research (2nd ICBER, 2011) Proceeding, 2011-279.

[32] Sutton, D. \& Klein, T. (2003). "Enterprise marketing management", John Wiley \& Sons, NewYork, pp. 1-22. 
Bulletin de la Société Royale des Sciences de Liège, Vol. 86, special edition, 2017, p.421 - 433

[33] Wahab, N. A., Hassan, L. F. A., Shahid, S. A. M., \& Maon, S. N. (2016). The Relationship between Marketing Mix and Customer Loyalty in Hijab Industry: The Mediating Effect of Customer Satisfaction. Procedia Economics and Finance, 37, 366371.

[34] Wahab, N. A., Hassan, L. F. A., Shahid, S. A. M., \& Maon, S. N. (2016). The Relationship between Marketing Mix and Customer Loyalty in Hijab Industry: The Mediating Effect of Customer Satisfaction. Procedia Economics and Finance, 37, 366371.

[35] Wang, X., Sha, Z., \& Kwong, K. (2008, October). Effects of Brand Image and Manufacture-3PL Relationship on 3PL Satisfaction: A Theoretical Framework. In 2008 4th International Conference on Wireless Communications, Networking and Mobile Computing (pp. 1-4). IEEE.

[36] Yau, O. H., McFetridge, P. R., Chow, R. P., Lee, J. S., Sin, L. Y., \& Tse, A. C. (2000). Is relationship marketing for everyone?. European Journal of Marketing, 34(9/10), 11111127.

[37] Yi, Y., \& La, S. (2004). What influences the relationship between customer satisfactions and repurchase intention? Investigating the effects of adjusted expectations and customer loyalty. Psychology \& Marketing, 21(5), 351-373.

[38] Zins, A. H. (2001). Relative attitudes and commitment in customer loyalty models: Some experiences in the commercial airline industry. International Journal of Service Industry Management, 12(3), 269-294. 